\title{
Down-regulation of microRNA-155 promotes selenium deficiency-induced apoptosis by tumor necrosis factor receptor superfamily member 1B in the broiler spleen
}

\author{
Ci Liu ${ }^{1}$, Zhepeng Sun ${ }^{1}$, Zhe Xu ${ }^{1}$, Tianqi Liu ${ }^{1}$, Tingru Pan ${ }^{1}$ and Shu Li $^{1}$ \\ ${ }^{1}$ College of Veterinary Medicine, Northeast Agricultural University, Harbin 150030, P. R. China \\ Correspondence to: Shu Li, email: lishu@neau.edu.cn \\ Keywords: broiler, spleen, lymphocyte apoptosis, microRNA-155, tumor necrosis factor receptor superfamily member 1B \\ Received: February 03, $2017 \quad$ Accepted: March 22, $2017 \quad$ Published: April 19, 2017 \\ Copyright: Liv et al. This is an open-access article distributed under the terms of the Creative Commons Attribution License 3.0 (CC \\ BY 3.0), which permits unrestricted use, distribution, and reproduction in any medium, provided the original author and source are \\ credited.
}

\section{ABSTRACT}

The aim of this work was to explore the microRNA profile and the effect of microRNA-155 on apoptosis in the spleen of selenium-deficient broilers. We replicated the splenic-apoptotic model in selenium-deficient broilers. In vitro, microRNA-155 oligonucleotides were transfected into lymphocytes and subsequently treated with $\mathrm{H}_{2} \mathrm{O}_{2}$. We observed that selenium deficiency altered the microRNA profile and decreased the expression of microRNA-155 in the broiler spleens. Tumor necrosis factor receptor superfamily member 1B was verified as a target of microRNA-155 in the splenocytes. Morphological changes, increased levels of tumor necrosis factor receptor superfamily member $1 \mathrm{~B}, \mathrm{C}-J$ un $\mathrm{N}$-terminal kinase, Bak, Bax, Cyt-C, caspase 9 and caspase 3 and decreased levels of $\mathrm{Bcl}-2$ demonstrated that selenium deficiency induced apoptosis in the spleen tissues. In vitro, microRNA-155 m inhibited the levels of ROS and reduced apoptosis compared with microRNA-155i in the lymphocytes. These results suggested that the reduced levels of microRNA-155 due to selenium deficiency could promote oxidative stress-induced apoptosis by increased tumor necrosis factor receptor superfamily member $1 B$ in splenic cells.

\section{INTRODUCTION}

The essential trace mineral selenium is of fundamental importance in animal health. Selenium plays a crucial role in immunomodulation [1]. Selenium supplementation can improve the immune function of animals [2]. Selenium modulates the immune response by protecting lymphocytes from the effects of inhibitory products and maintaining the integrity of cellular membranes [3]. However, selenium deficiency or lowselenium status may negatively affect immune cells, such as reducing the maturation of specific subpopulations and proliferative capabilities of lymphocytes; blocking biosynthesis in macrophages and decreasing the antioxidation and bactericidal ability of neutrophils [4-6]. Selenium deficiency also impaired the host innate immune response by inducing changes in the levels of cytokine expression in the spleens of mice [7]. Furthermore, selenium deficiency aggravates the caspase3-dependent apoptosis induced by $\mathrm{H}_{2} \mathrm{O}_{2}$ in primary cultures of pig thyroid cells [8]. The caspase-dependent apoptotic pathway was up-regulated by selenium deficiency in myocardial of rats [9]. Selenium deficiency induced apoptosis and linked the oxidative and endoplasmic reticulum stress pathways in the skeletal muscles (wing, pectoral, and thigh) and livers of laying hens $[10,11]$. Apoptosis linked to nitric oxide was induced by selenium deficiency in the immune organs of laying hens [12].

MicroRNAs are a class of short (21-25 nt), noncoding RNAs that are evolutionarily conserved from plants to mammals and they control the expression of their target genes at the post-transcriptional level [13]. Apoptosis is an intrinsic cellular mechanism and can be stimulated by various microRNAs. miRs function as either pro- or antiapoptotic factors mainly by binding to the 3 -untranslated region (3'UTR) of their target mRNA resulting in mRNA cleavage and/or translational inhibition to prevent the expression of the corresponding protein [14]. miR-155 represents a typical multifunctional microRNA in the immune system that affects cell activation, proliferation 
and differentiation [15-18]. Available experimental evidence demonstrates that microRNA-155 can mediated inhibition of apoptosis by interacting with its downstream targets in various cell lines [19, 20]. Furthermore, the selenium supply can alter the microRNA expression profile. Microarray analysis (737 microRNAs in total) of the microRNA profile of Caco-2 cells growing in selenium-deficient or selenium-supplemented medium revealed that the expression of 12 microRNAs were affected by the selenium supply [21]. Among the 621 microRNAs detected by GeneChip, microRNA222, microRNA2393, and microRNA2300b were significantly affected by selenium supplementation in the liver tissues of maturing beef [22].

In summary, selenium deficiency could cause immune dysfunction and damages to the immune organs in chickens. In this study, our aim was to investigate the effects of selenium deficiency on the microRNA profile and the mechanism of microRNAs in apoptosis of splenic cells. Therefore, we successfully reproduced the model of selenium-deficient broilers. We found that selenium deficiency altered the microRNA profile and reduced the expression of microRNA-155 in the tissues of the spleen. In addition, tumor necrosis factor receptor superfamily member 1B (TNFRSF1B) was predicted as one of the microRNA-155 targets in broilers. Based on the pivotal role of TNFRSF1B in the apoptotic pathway, we performed experiments both in vivo and in vitro. The results demonstrated that TNFRSF1B was a target of microRNA-155 in the splenic cells. Reduced levels of microRNA-155 promoted apoptosis by targeting TNFRSF1B in the spleen tissues of broilers suffering from selenium deficiency. This study explored the role of selenium deficiency in apoptosis to determine the signal transduction pathways involved, and the findings will help to elucidate the biological mechanisms in which selenium is involved.

\section{RESULTS}

\section{Results of microRNA profile in spleen tissues}

To identify the potential microRNA signatures, we generated the expression profile of microRNA as shown in Figure 1A-1C. The comparison showed that the expression profiles of spleen tissues from the $\mathrm{C}$ group and L group were highly correlated (Pearson correlation, $\left.r^{2}=0.972\right)$. Further examination revealed that
A

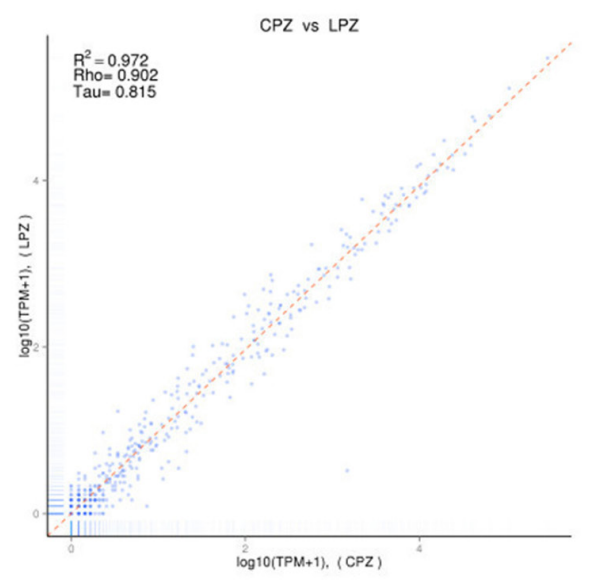

C

\begin{tabular}{lc}
\hline Direction of regulation & Number \\
\hline Analysis of total microRNAs & 657 \\
Analysis of differential microRNAs & 386 \\
Down-regulations of microRNAs & 181 \\
Up-regulations of microRNAs & 205 \\
\hline
\end{tabular}

B

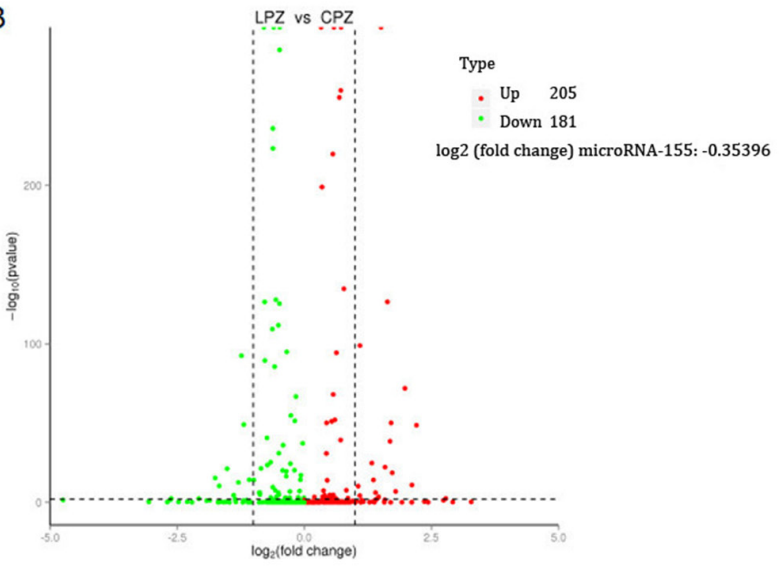

$\mathrm{D}$

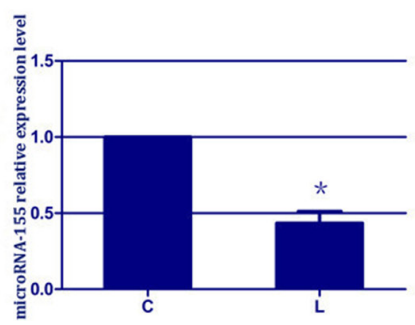

Figure 1: The results of microRNA expression profile and microRNA-155 in spleen tissues. (A) represents the correlation analysis of global microRNAs expression. The scatter plot of genome-wide microRNA expression between $\mathrm{C}$ and $\mathrm{L}$ groups $\left(\right.$ Pearson $\mathrm{r}^{2}=$ 0.98). (B) indicates volcano map for different microRNA. X coordinate indicate the fold change, Y coordinate indicate the significance, red dot are up regulated microRNA, green dot are down regulated microRNA, blue dot are not different microRNA. (C) represents the results of all microRNAs differential analysis. Each value comes from three individuals. (D) exhibits the results of microRNA-155 in spleen tissue of selenium-deficient broiler. Bars with “*” indicated that there are significant differences $(P<0.05)$ between $\mathrm{C}$ group and L group. Each value represented the mean $\pm \mathrm{SD}$ of five individuals. 
386 microRNAs were differentially expressed among the 657 microRNAs between the $\mathrm{C}$ group and L group, the levels of 205 microRNAs increased and 181 microRNAs decreased in spleen tissues of broilers due to selenium deficiency. This suggested that the microRNA profile was altered due to selenium deficiency. Additionally, the $\log _{2}$ (fold change) value for microRNA-155 was -0.35396, indicating that microRNA-155 was significantly downregulated in the spleen tissues of selenium-deficient broilers. We assessed the expression of microRNA-155 by RT-PCR. As shown in Figure 1D, the expression of microRNA-155 in the L group was significantly reduced to $\sim 43 \%(P<0.05)$ compared with the $\mathrm{C}$ group. These results suggested that selenium deficiency altered the microRNA expression profile and reduced the expression of microRNA-155.

\section{Morphological observations of broiler spleens}

We used transmission electron microscopy to study apoptosis in the broiler splenic cells. As shown in Figure 2A, the spleens of broilers in the $\mathrm{C}$ group displayed that the normal morphologies. However, many typical apoptotic features appeared in the splenic cells of selenium-deficient broilers, including smaller cell volume, increased cytoplasmic color, vacuole formation in the cytoplasm, marked accumulation of chromatin or the formation of crescent-shaped aggregates at the nuclear membrane. All these observed features confirmed that selenium deficiency could induce apoptosis in the broiler spleen and that we had successfully reproduced the apoptotic model.

\section{Expression of apoptotic genes in the broiler spleens}

To better understand the effects of selenium deficiency on apoptosis, we evaluated the expression of apoptotic genes by RT-PCR and WB in broiler spleens. As shown in Figure 2B-2D, we examined the expression of TNFRSF1B, JNK, Bcl-2, Bax, Bak, Cyt-c, caspase9 and caspase 3 in this study. Except for Bcl-2, the expression
A

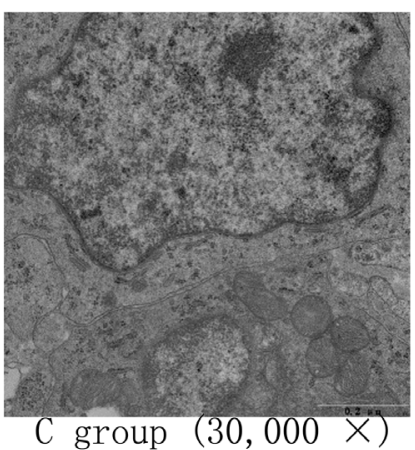

C group $(30,000 \times)$

C

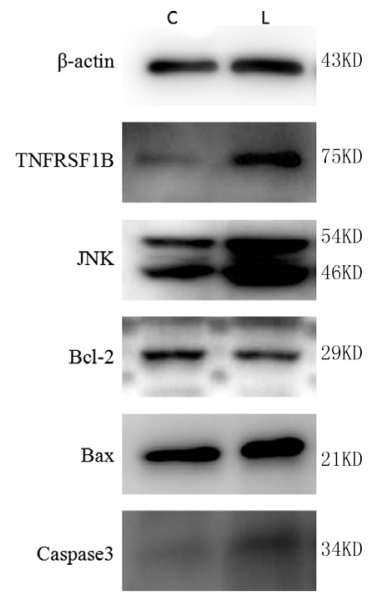

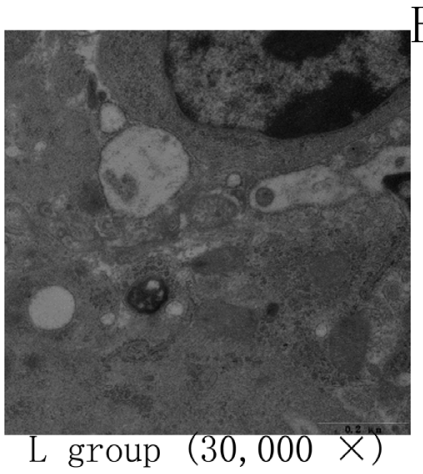

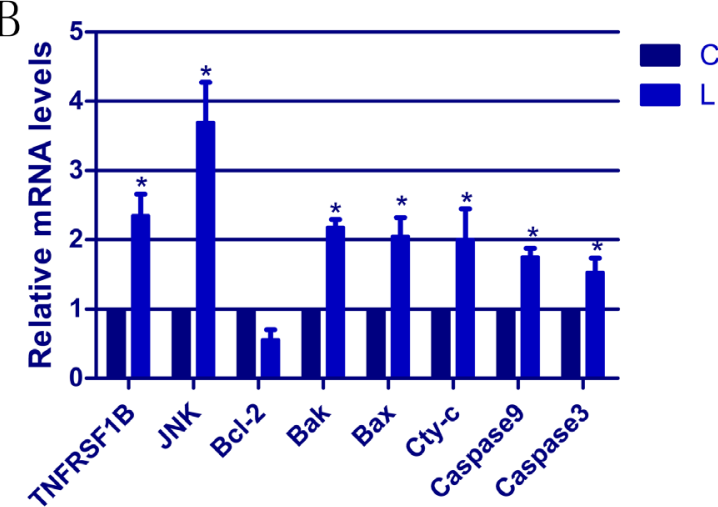

$\mathrm{D}$

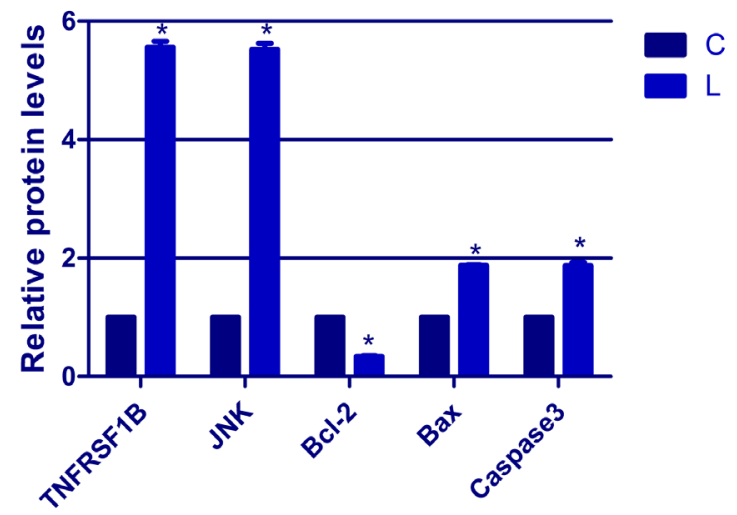

Figure 2: The ultrastructural changes and the expressions of apoptotic genes in spleen of selenium deficiency broiler. (A) represents the ultrastructural change of splenic cells. (B) represents the mRNA expression of apoptosis genes in spleen tissues of broiler. (C) represents immunoblotting of $\beta$-actin, TNFRSF1B, JNK, Bcl-2, Bax and caspase 3 in spleen tissues. (D) represents respectively the protein expression of apoptosis genes. Bars with “*” indicated that there are significant differences $(P<0.05)$ between $\mathrm{C}$ group and L group. Each value represents the mean \pm SD of five individuals. 
of the rest of the genes was increased in the lymphocytes compared with the corresponding $\mathrm{C}$ group, and most of the differences were statistically significant $(P<0.05)$. The mRNA and protein levels of Bcl-2 were significantly reduced in comparison to the $\mathrm{C}$ group. These data verified that selenium deficiency could induce apoptosis in broiler spleens.

\section{Transfection efficiency of microRNA-155 in the splenic lymphocytes}

To test the efficacy of the synthetic microRNA oligonucleotides, we transfected them into cultured lymphocytes and evaluated expression of microRNA-155 by RT-PCR. As expected, compared with the C group, the level of microRNA-155 was significantly increased by 7.97 times in the microRNA-155 m group, whereas it was decreased to $47 \%$ in the microRNA-155i group as shown in Figure 3A. Thus, the microRNA oligonucleotides used in this study were effective and thus could be used for subsequent experiments.

\section{TNFRSF1B is a target of microRNA-155 in lymphocytes}

To study the mechanism by which microRNA-155 causes apoptosis in lymphocytes, the miRDB software was used. We found that TNFRSF1B was a potential target of miR-155 as shown in Figure 3B. The TNFRSF1B 3'UTR has a binding site for microRNA-155, suggesting that TNFRSF1B may be a direct target of microRNA-155. Therefore, we tested whether the over-expression of microRNA-155 could lead to the down-regulation of TNFRSF1B expression in lymphocytes.

To understand if the relationship between microRNA-155 and TNFRSF1B was that of negative
A

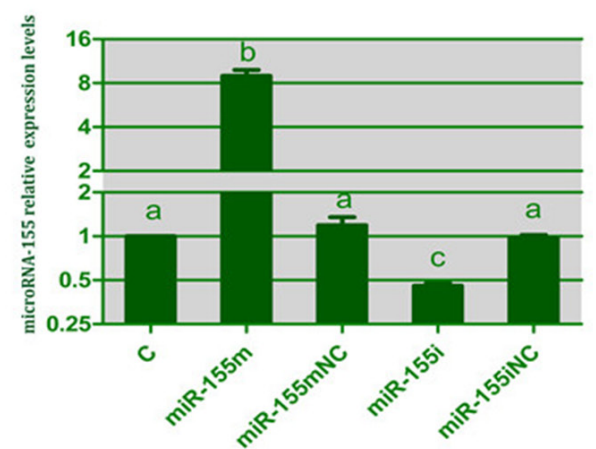

C

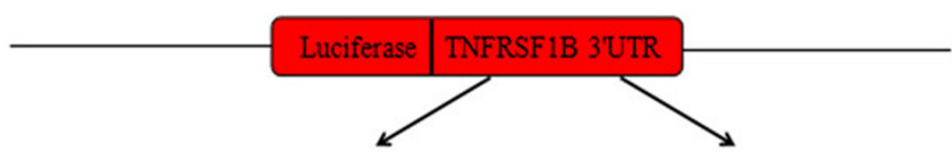

Wild Type 3' 5'...UCACGUCUAAACAAUAGCAUUAU..

UTR 3 '... GGGGAUAGUGCUAAUCGUAAUU...

gga-miR-155 5 '...UCACGUCUAAACAAUGUAGAGU...

$\mathrm{E}$

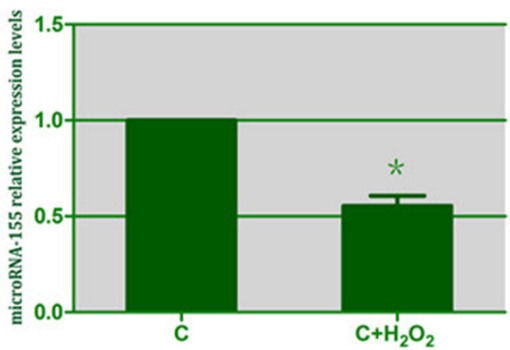

B

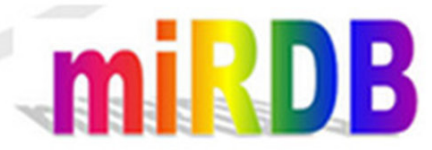

MicroRNA and Target Gene Description:

miRNA Name gga-miR-155 miRNA Sequence UUAAUGCUAAUCGUGAUAGGGG

Target Score $71 \quad$ Seed Location 552

NCBI Gene ID $\underline{395083} \quad \begin{aligned} & \text { GenBank } \\ & \text { NM_204439 }\end{aligned}$

Gene Symbol TNFRSF1B 3' UTR Length 1490

Gene

tumor necrosis factor receptor superfamily, member 18

$\mathrm{D}$

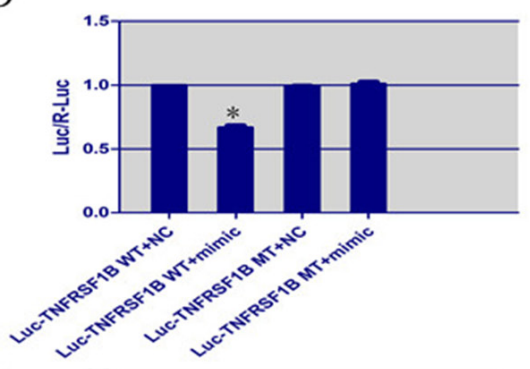

F

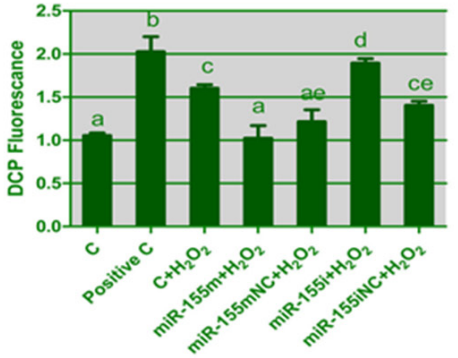

Figure 3: The results of TNFRSF1B as a target of microRNA-155 and the results of ROS induced by $\mathrm{H}_{2} \mathrm{O}_{2}$ in lymphocytes. (A) represents the transfection efficiency of microRNA-155 in spleen lymphocytes. (B) represents TNFRSF1B as a predicted target of miR155 by miRDB software. (C) represent the sequences of wild-type or mutant 3'UTR of TNFRSF1B and microRNA-155. (D) represents the results of dual luciferase reporter gene assay. (E) represents the levels of microRNA-155 in lymphocytes treated by $\mathrm{H}_{2} \mathrm{O}_{2}$. (F) denotes the effect of microRNA-155 on levels of ROS in lymphocytes. The different small letters indicate that there are significant differences $(P<$ 0.05 ) between any two groups. Each value represents the mean \pm SD of three individuals. 
regulation, we constructed plasmids containing wildtype or mutant-type 3'UTR of TNFRSF1B fused to the luciferase gene (Figure 3C). The wild-type or mutant plasmid was co-transfected into cardiomyocytes with microRNA-155 m or microRNA-155 mNC. As shown in Figure 3D, microRNA-155 significantly decreased the luciferase activity of the wild-type 3'UTR of TNFRSF1B but not the one with the mutant 3'UTR of TNFRSF1B, suggesting that microRNA-155 could directly bind to the 3'UTR of TNFRSF1B.

\section{Effect of $\mathrm{H}_{2} \mathrm{O}_{2}$ on microRNA-155 expression and the level of ROS in lymphocytes}

As shown in Figure 3E, we evaluated the effects of $\mathrm{H}_{2} \mathrm{O}_{2}$ on the expression of microRNA-155 in lymphocytes by RT-PCR. The microRNA-155 level was inhibited by $45 \%$ in the lymphocytes treated with $\mathrm{H}_{2} \mathrm{O}_{2}$ compared to the control lymphocytes. This showed that $\mathrm{H}_{2} \mathrm{O}_{2}$ could reduce the expression of microRNA-155 in lymphocytes.

To explore the protective effect of microRNA-155 on $\mathrm{H}_{2} \mathrm{O}_{2}$-induced oxidative stress in lymphocytes,

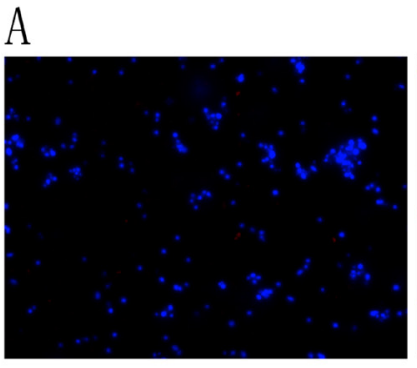

C

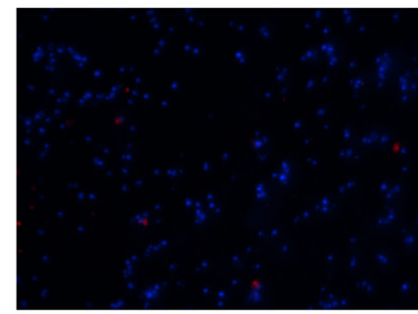

miR $-155 m+\mathrm{H}_{2} \mathrm{O}_{2}$

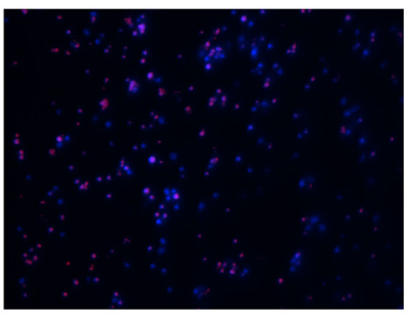

$\operatorname{miR}-155 \mathrm{i}+\mathrm{H}_{2} \mathrm{O}_{2}$

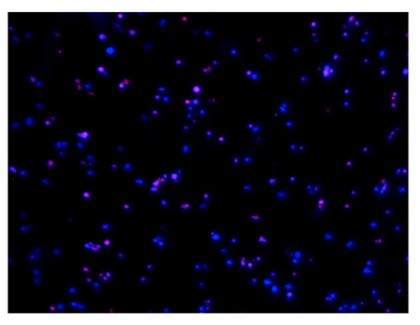

$\mathrm{C}+\mathrm{H}_{2} \mathrm{O}_{2}$

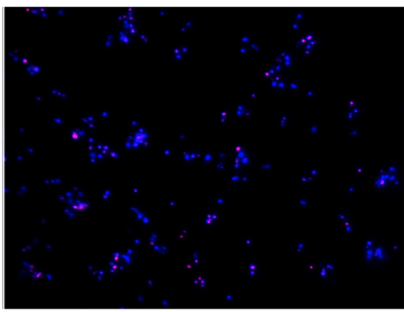

$\mathrm{miR}-155 \mathrm{mNC}+\mathrm{H}_{2} \mathrm{O}_{2}$

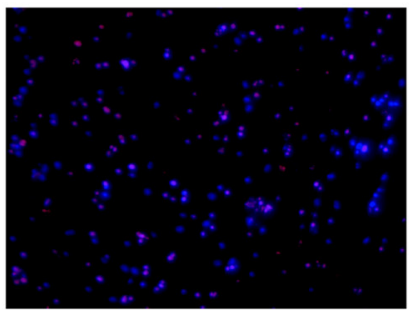

$\mathrm{miR}-155 \mathrm{iNC}+\mathrm{H}_{2} \mathrm{O}_{2}$

we tested the levels of ROS as shown in Figure 3F. From the results of this assay, it was evident that $\mathrm{H}_{2} \mathrm{O}_{2}$ significantly increased the level of $\operatorname{ROS}(P<0.05)$. In the microRNA-155 m group, the level of ROS was significantly altered in comparison with the $\mathrm{H}_{2} \mathrm{O}_{2}$ group. In the microRNA-155i group, the $\mathrm{H}_{2} \mathrm{O}_{2}$-induced ROS was increased. These data suggested that microRNA-155 had a protective effect on the lymphocytes against the $\mathrm{H}_{2} \mathrm{O}_{2}$ induced oxidative stress.

\section{Effect of microRNA-155 on apoptotic morphology}

To estimate the effect of microRNA-155 on $\mathrm{H}_{2} \mathrm{O}_{2}$ induced apoptosis in lymphocytes, we used the TUNEL staining with DAPI and AO/EB.

As shown in Figure 4A, the apoptotic lymphocytes are represented in red. We found very few apoptotic cells in the $\mathrm{C}$ group. However, the $\mathrm{H}_{2} \mathrm{O}_{2}$-treated group displayed a higher degree of apoptosis than the $\mathrm{C}$ group, and microRNA-155 was able to reduce the occurrence of apoptosis induced by $\mathrm{H}_{2} \mathrm{O}_{2}$. However, microRNA-155i

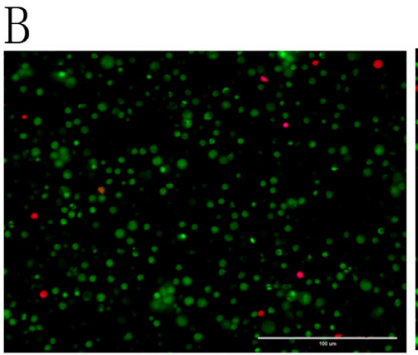

C

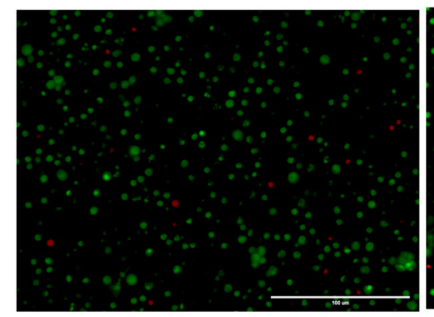

miR $-155 m+\mathrm{H}_{2} \mathrm{O}_{2}$

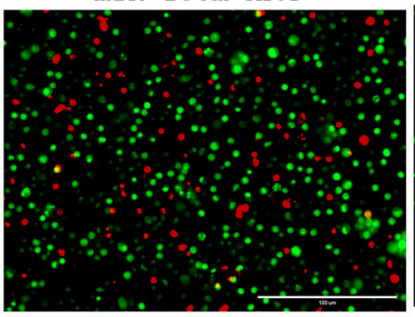

$\operatorname{miR}-155 \mathrm{i}+\mathrm{H}_{2} \mathrm{O}_{2}$

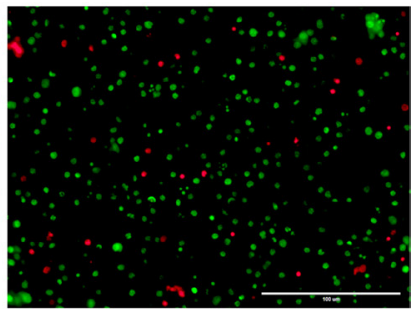

$\mathrm{C}+\mathrm{H}_{2} \mathrm{O}_{2}$

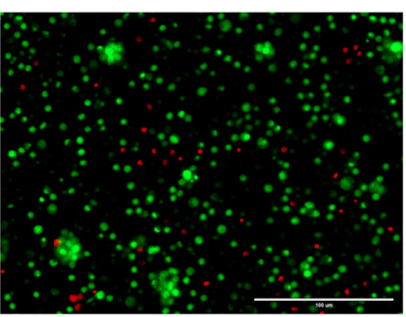

$\mathrm{miR}-155 \mathrm{mNC}+\mathrm{H}_{2} \mathrm{O}_{2}$

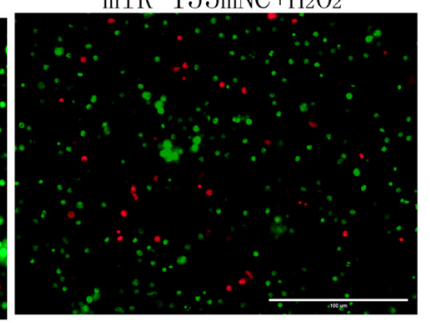

miR-155iNC+ $\mathrm{H}_{2} \mathrm{O}_{2}$

Figure 4: The effects of microRNA-155 on apoptotic morphology. (A) Detection results of TUNEL staining with DAPI (magnification $\times 200$ ) of the lymphocytes. Dyed blue represent normal cells. The apoptotic lymphocytes are stained by red. (B) Detection results of staining with $\mathrm{AO} / \mathrm{EB}$ (magnification $\times 400$ ) of the lymphocytes. The normal lymphocytes are stained by green. The early apoptotic lymphocytes are stained by bright green, and later apoptotic lymphocytes are stained by orange. The necrotic lymphocytes are stained by red. 
increased the severity of apoptosis, and there was no significant difference between the microRNA-155 mNC and microRNA-155iNC groups.

As shown in Figure 4B, the cells stained in light green, orange and red, represented cells undergoing early apoptosis, late apoptosis and necrosis, respectively. We observed only a few apoptotic lymphocytes in the $\mathrm{C}$ group. After treatment by $\mathrm{H}_{2} \mathrm{O}_{2}$, more cells were stained bright green, orange and red in comparison with the $\mathrm{C}$ group. In the microRNA-155 m group, there were more green lymphocytes than in the $\mathrm{H}_{2} \mathrm{O}_{2}$ group. The number of apoptotic and necrotic lymphocytes was the highest in the microRNA-155i group. These results revealed that the decreased microRNA-155 promoted apoptosis induced by $\mathrm{H}_{2} \mathrm{O}_{2}$ in lymphocytes.

\section{Effects of microRNA-155 on apoptosis in lymphocytes}

To confirm the relation between apoptosis and microRNA-155, we evaluated the mRNA and protein levels of apoptosis-related genes in lymphocytes by RTPCR and WB. As shown in Figure 5, when compared with the $\mathrm{H}_{2} \mathrm{O}_{2}$ group, in the microRNA-155i group treated with $\mathrm{H}_{2} \mathrm{O}_{2}$ the expression of TNFRSF1B, JNK, Bak, Bax, Cyt-c, caspase 3 and caspase 9 was significantly increased. This was consistent with that in the spleen tissues of seleniumdeficient broilers. The levels of TNFRSF1B, JNK, Bak, Bax, Cyt-c, caspase9 and caspase 3 in the microRNA$155 \mathrm{~m}$ group, were decreased by $\mathrm{H}_{2} \mathrm{O}_{2}$ compared with the $\mathrm{H}_{2} \mathrm{O}_{2}$ group. The mRNA and protein levels of $\mathrm{Bcl}-2$ were significantly reduced in the microRNA-155i group after treatment with $\mathrm{H}_{2} \mathrm{O}_{2}$. These data demonstrated that the reduced expression of microRNA-155 could promote $\mathrm{H}_{2} \mathrm{O}_{2}$-induced apoptosis in the lymphocytes.

\section{DISCUSSION}

Selenium deficiency can lead to a variety of pathological reactions in immune organs (including spleen, thymus and bursa of Fabricius) in chickens, such as dysfunction in immune regulation, oxidative
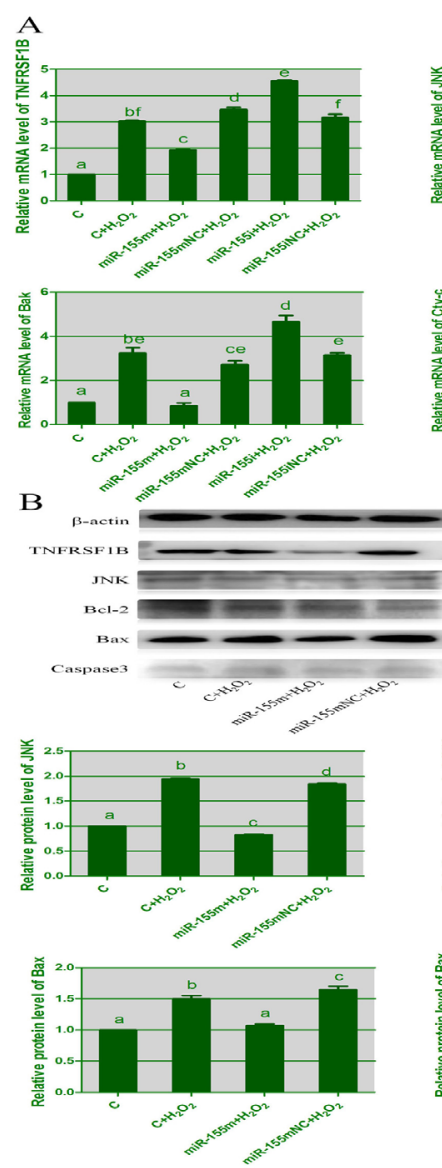
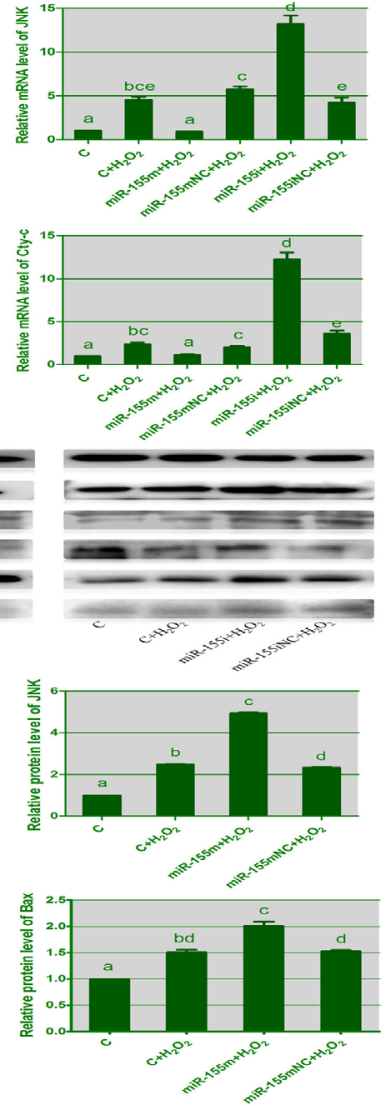

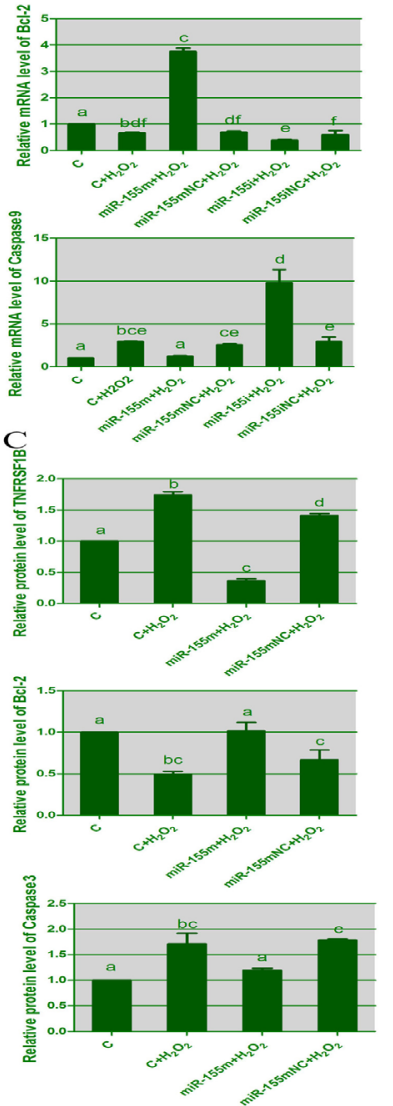

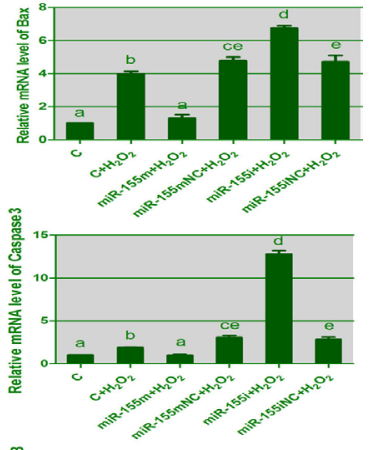
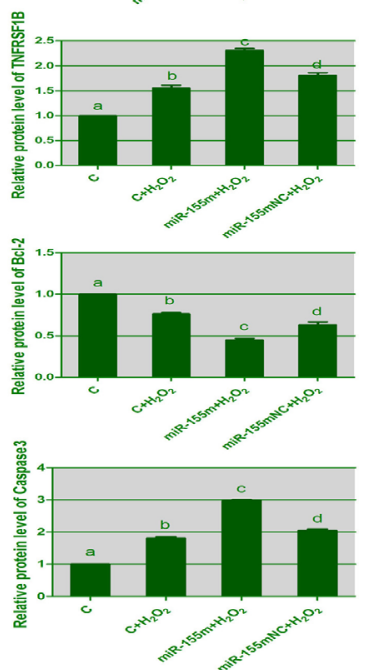

Figure 5: The effects of microRNA-155 on apoptosis in lymphocytes. (A) represents the mRNA expression of apoptosis genes in lymphocytes. (B) represents immunoblotting of $\beta$-actin, TNFRSF1B, JNK, Bcl-2, Bax and caspase3 in lymphocytes from different groups. (C) represents the protein expression of apoptosis genes. The different small letters indicate that there are significant differences $(P<0.05)$ between any two groups. Each value represents the mean \pm SD of three individuals. 
stress, inflammation caused by variants of selenoprotein genes, etc.[23-25]. However, how selenium deficiency stimulates the expression of microRNAs in broiler spleen has not been studied yet. The results from the present study indicated that selenium deficiency could alter the microRNA profile in broiler spleens. From the 657 entities included on the microRNA chip, the expressions of 386 microRNAs were found to be significantly altered following selenium deficiency. Macieldominguez et al. have reported that selenium supply could significantly affect 12 microRNAs out of 737 microRNAs in Caco-2 cells [21]. Among 621 microRNAs, only 3 microRNAs were shown to be altered by an selenium supplementation treatment in liver tissues of maturing beef [22]. The difference in the number of altered microRNAs between our results and others is probably because of the different cell types and/or different concentrations of selenium used. Among the 181 microRNAs inhibited in the present study, the expression of microRNA-155 was down-regulation due to selenium deficiency. Further analysis by RT-PCR revealed that the level of microRNA-155 was indeed reduced in the spleen tissues of broilers after selenium deficiency.

microRNA-155, an important multifunctional microRNA, has many target genes. The direct targets of microRNA-155 have been experimentally validated, including SOCS1 [26, 27], FADD, RIPK1 [28], TP53INP1 [29], MAP3K7IP2 [30], etc. In this study, we provided several lines of evidence indicating that TNFRSF1B was the target of microRNA-155 in the lymphocytes. On one hand, microRNA-155 was predicted to bind to the seed sequence of TNFRSF1B mRNA in the miRDB software. Additionally, microRNA-155 over-expression inhibited the luciferase activity of TNFRSF1B 3'UTR in wild-type, but not the mutant-type. Furthermore, the over-expression and/or knockdown of microRNA-155 respectively downregulated and/or up-regulated the TNFRSF1B expression in the lymphocytes. Therefore, TNFRSF1B was one target of microRNA-155 in lymphocytes.

Being a TNF receptor, TNFRSF1B is expressed in a limited subset of cells such as CD4 and CD8 T lymphocytes, thymocytes, and cardiac myocytes. There are a number of studies showing that TNFRSF1B has the ability to inhibit apoptosis and activate survival pathways [31-33]. However, only a small number of reports showed that TNFRSF1B could accelerate the process of apoptosis, particularly in T cells. For example, Pimentel and Seed demonstrated that the ability of TNFRSF1B to initiate apoptosis was dependent on high levels of RIP expression in T cells [34]; Peter Vandenabeele and colleagues reported that in the rat/mouse T cell hybridoma PC60, TNFRSF1B could generate pro-apoptotic signal independently of

\section{microRNA-155 Signaling Pathway in Lymphcyte}

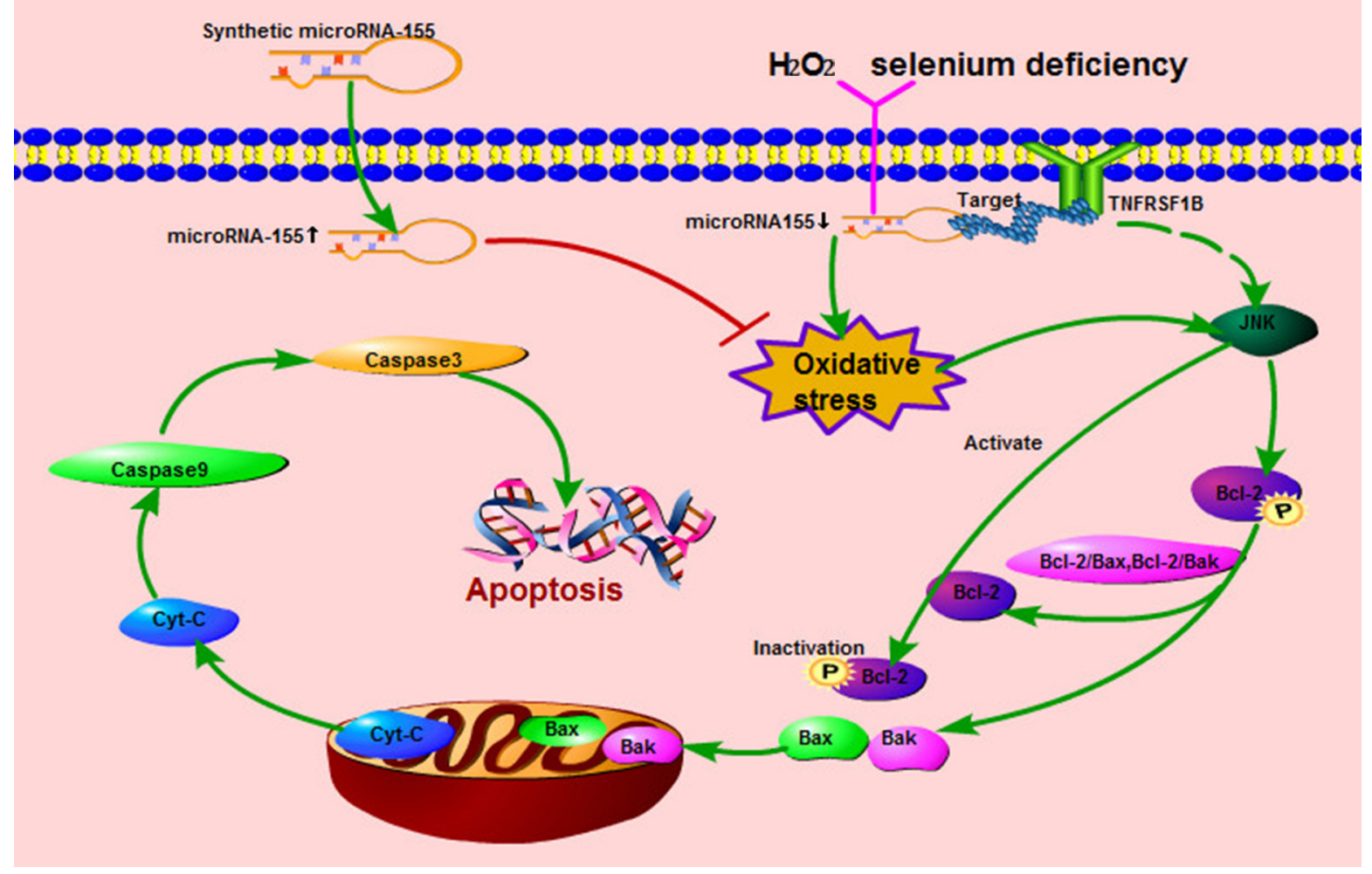

Figure 6: The apoptotic signaling pathway of microRNA-155 in splenic lymphocytes. 
Table 1: microRNAs and mRNAs primer sequences

A

\begin{tabular}{|c|c|c|c|c|}
\hline Gene & \multicolumn{2}{|c|}{ Forward primer (5'-3') } & \multicolumn{2}{|c|}{ Reverse primer (5'-3') } \\
\hline $\operatorname{miR}-155$ & \multicolumn{2}{|c|}{ GGCTTAATGCTAATCGTGATAGGGGT } & \multicolumn{2}{|c|}{ Provided by Tiangen Biotech Co. Ltd. } \\
\hline U6 & \multicolumn{2}{|c|}{ CACGCAAATTCGTGAAGCGTTCCA } & \multicolumn{2}{|c|}{ Provided by Tiangen Biotech Co. Ltd. } \\
\hline \multicolumn{5}{|l|}{ B } \\
\hline Genes & Serial number & $\begin{array}{l}\text { Forward primer }( \\
\text { Reverse primer }(5\end{array}$ & & Product size (bp) \\
\hline TNFRSF1B & XM_015296812 & $\begin{array}{l}\text { F:TGCCTACTCA } \\
\text { R:AGATGCTGCT }\end{array}$ & $\begin{array}{l}\text { AACTG } \\
\text { TGTTC }\end{array}$ & 126 \\
\hline JNK & XM_015288440.1 & $\begin{array}{l}\text { F:GCATCCATCT1 } \\
\text { R:TCATCTACAG }\end{array}$ & $\begin{array}{l}\text { GTCAT } \\
\text { CAGAGG }\end{array}$ & 121 \\
\hline Bcl-2 & D11382.2 & $\begin{array}{l}\text { F:ATCGTCGCCT } \\
\text { R:ATCCCATCCTC }\end{array}$ & $\begin{array}{l}\text { JAGTT } \\
\text { GTCCT }\end{array}$ & 150 \\
\hline Bak & NM_001030920.1 & $\begin{array}{l}\text { F:ACCCGGAGAT } \\
\text { R:GATGCCTTGC }\end{array}$ & $\begin{array}{l}\mathrm{AGA} \\
\mathrm{GACG}\end{array}$ & 272 \\
\hline Bax & XM_422067.2 & $\begin{array}{l}\text { F:GTGATGGCAT } \\
\text { R:TGGCGTAGAC }\end{array}$ & $\begin{array}{l}\text { ATAGCTC } \\
\text { GGATAA }\end{array}$ & 90 \\
\hline Cty-c & K02303.1 & $\begin{array}{l}\text { F: AGGCAAGCA } \\
\text { R: CTGACTATCA }\end{array}$ & $\begin{array}{l}\text { CTGGA } \\
\text { JAACCACC }\end{array}$ & 150 \\
\hline caspase 3 & NM_204725.1 & $\begin{array}{l}\text { F:CTGAAGGCTC } \\
\text { R:TGCCACTCTG }\end{array}$ & $\begin{array}{l}\text { TTA } \\
\text { TAC }\end{array}$ & 104 \\
\hline caspase 9 & XM_424580.3 & $\begin{array}{l}\text { F:CCGAAGGAGC } \\
\text { R:AGGTTGGACT }\end{array}$ & $\begin{array}{l}\text { ACG } \\
\text { ГGGAC }\end{array}$ & 243 \\
\hline$\beta$-actin & L08165 & $\begin{array}{l}\mathrm{F}: \text { CCGCTCTATG } \\
\text { R:CTCTCGGCTG }\end{array}$ & $\begin{array}{l}\text { TACGC } \\
\text { GTGAA }\end{array}$ & 128 \\
\hline
\end{tabular}

A represents microRNAs primer sequences; B represents mRNAs primer sequences.

TNFR1 [35]; Additionally, Ramesh and Reeves reported that apoptosis were reduced in TNFRSF1B-deficient mice [36]. Therefore, the expression of TNFRSF1B was used as an index for the evaluation of apoptosis in this study. This study is the first to report that the expression of TNFRSF1B mRNA and protein was induced by selenium deficiency in the broiler spleen. According to KEGG, we obtained that TNFRSF1B (TNFR2) could participate into JNK pathway to induce apoptosis, and there were studies also reported that the over-expression of TNFRSF1B indirectly mediated a signal for apoptosis by activating JNK $[37,38]$. In this work, the levels of JNK mRNA and protein were increased with the increase in TNFRSF1B due to selenium deficiency. JNK, a major regulator of apoptosis, could alter the levels of the Bcl-2 family of proteins. The Bcl-2 family has both anti-apoptotic member (Bcl-2) and pro-apoptotic members (Bax and Bak) involved in the mitochondrial apoptotic signal pathway [39]. JNK can lead to Bcl-2 phosphorylation at multiple sites to promote the dissociation of the $\mathrm{Bcl}-2 / \mathrm{Bax}$ complex [40]. The dissociated Bax can directly induce Cyt-c release from the mitochondria [41]. Cyt-c can then activate caspase 9 and the downstream signal caspase 3 resulting in the mitochondrial apoptotic cascade [42-44]. Our results suggested that the up-regulation of TNFRSF1B due to selenium deficiency might indirectly stimulate JNK signaling to participate in the mitochondrial apoptotic process, but the detailed mechanisms need further study.

Selenium is thought to protect macromolecules and membrane lipids from oxidative damage by combating ROS [45], and selenium deficiency and $\mathrm{H}_{2} \mathrm{O}_{2}$ can increase oxidative damage and cause apoptosis [46-48]. In this study, both selenium deficiency and $\mathrm{H}_{2} \mathrm{O}_{2}$ reduced the expression of microRNA-155. To further ascertain whether microRNA-155 decreased oxidative stress-induced apoptosis in the splenic cells by regulating TNFRSF1B, the lymphocytes were transfected with microRNA-155 $\mathrm{m}$ and microRNA-155i followed by exposure to $\mathrm{H}_{2} \mathrm{O}_{2}$. From the results of ROS and analysis of the expression of apoptosis-related genes, we found that microRNA-155 
could promote oxidative stress-induced apoptosis in the lymphocytes by activating JNK [49]. microRNA-mediated inhibition of apoptosis by binding to their targets has been reported in immune cell lines. The over-expression of microRNA-23a/b repressed apoptosis in thymic lymphoma cells by targeting Fas [50]. Transfection of microRNA-22 mimics directly targeted the galectin-9 3'UTR-suppressed apoptosis in peripheral blood mononuclear cells [51]. Additionally, Koch and Meyer have reported that microRNA-155 prevent apoptosis caused by DNA damage in macrophages [52]. We also demonstrated that the up-regulation of microRNA-155 contributed to downregulating the expression of TNFRSF1B, which could act a protective mechanism against the oxidative stressmediated mitochondrial apoptotic signaling pathway mediated by $\mathrm{H}_{2} \mathrm{O}_{2}$ in the lymphocytes. Our previous study demonstrated that selenium could induced oxidative stress in broiler spleens [24], By taking the present results into consideration, we concluded that the microRNA-155 signaling pathway in lymphocytes can be described as shown in Figure 6.

\section{CONCLUSIONS}

In summary, the present work demonstrated that selenium deficiency could alter the microRNA expression profile and reduce the expression of microRNA-155 in broiler spleens. TNFRSF1B was found to be a target of microRNA-155 in the broiler splenic cells. The reduced microRNA-155 levels in the spleen tissues of seleniumdeficient broilers might promote the oxidative stressmediated apoptotic signaling pathway by stimulating TNFRSF1B. Our findings provide a potential novel therapeutic target for selenium deficiency-induced disease.

\section{MATERIALS AND METHODS}

\section{Reagents}

The following four synthetic, chemically modified short RNA oligonucleotides were purchased from Shanghai Gene Pharma Co. Ltd: microRNA-155 mimics (miR-155 m, Sense: 5'-UUAAUGCUAAUCGUGAUAGGGG-3', Anti-sense: 5'-CCUAUCACGAUUAGCAUUAAUU-3'), microRNA-155 mimics negative control (miR-155 mNC, Sense: 5'-UUCUCCGAACGAGUCACGUTT-3' Anti-sense: 5'-ACGUGACACGUUCGGAGAATT-3'), microRNA-155 inhibitors (miR-155i, 5'-CCCCUA UCACGAUUAGCAUUAA-3') and microRNA-155 inhibitors negative control (miR-155iNC, 5'-CAG UACUUUUGUGUAGUACAA-3'). The DualLuciferase $^{\circledR}$ Reporter Assay System and PhRL-TK were obtained from Promega. The pMICRORNA-REPORT Luciferase vector was supplied by ThermoFisher Co. Ltd. In addition, all the nucleotides used in this work were synthetized by biotech company. Other chemicals were provided by Harbin Baijiesi Technology Co., Ltd.

\section{Animal treatment}

All of the procedures used in the present study were approved by the Institutional Animal Care and Use Committee of Northeast Agricultural University. One hundred and fifty broilers (1-day-old; Heilongjiang Yisheng poultry Co. Ltd., Harbin, China) were randomly divided into two groups (75 chickens per group). The broilers were maintained either on a diet supplemented with selenium through the addition of $0.2 \mathrm{mg} / \mathrm{kg}$ selenium (C group)in the form of sodium selenite or on a seleniumdeficient granulated diet ( $\mathrm{L}$ group, from the seleniumdeficient region of Heilongjiang Province in China, containing $0.03 \mathrm{mg} / \mathrm{kg}$ selenium). The amount of selenium used in this study was determined based on the method by Yao et al. [53]. Feed and tap water were supplied ad libitum. When the symptoms of selenium deficiency appeared in the L group at $\sim 20$ days, the broilers were euthanized by cervical dislocation, and the spleen tissues were quickly collected. The tissues were excised immediately on ice, washed in a physiological saline solution and then stored at $-80^{\circ} \mathrm{C}$.

\section{microRNA detection and analysis in spleen tissues of broiler}

We extracted the total RNA from the spleen tissues of the $\mathrm{C}$ and $\mathrm{L}$ groups according to the manufacturer's instruction (Novogene Bioinformatics Technology Co., Ltd.). After quantification and qualification of the total RNA, the RNA was used as input material for the synthesis of small RNA libraries. The sequencing libraries were generated using NEBNext ${ }^{\circledR}$ Multiplex Small RNA Library Prep Set for Illumina ${ }^{\circledR}$ (NEB, USA) following the manufacturer's recommendations, and index codes were added to attribute the sequences to each sample. Raw data (raw reads) in fastq format were first processed through custom Perl and Python scripts. Bioinformatics analysis on the differential data from the of the two groups were performed using the DESeq R package. Corrected $P$-value of 0.05 was set as the threshold for significant differential expression by default.

\section{Ultrastructural observations}

The spleen tissues were fixed with $2.5 \%$ glutaraldehyde and rinsed twice for $15 \mathrm{~min}$ in $0.2 \mathrm{M}$ phosphate buffer ( $\mathrm{pH}$ 7.2). The samples were post-fixed in $1 \%$ buffered osmium tetroxide for $1 \mathrm{~h}$, dehydrated through a graded alcohol series and embedded in epoxy resin. Ultrathin sections were stained with uranyl acetate before examination under a transmission electron microscope [54]. 


\section{Cell culture and transfection}

Spleens were collected aseptically from the broilers (40-day-old) and placed in sterile phosphate-buffered saline (PBS; $0.1 \mathrm{~mol} / \mathrm{L}$ phosphate buffer with $0.85 \% \mathrm{NaCl}$, $\mathrm{pH}$ 7.2). Single cell suspensions were prepared by gently pushing the splenic pulp through sterile stainless steel mesh with a pore size of $200 \mu \mathrm{M}$. The cells were washed and resuspended in $5 \mathrm{~mL}$ sterile PBS and layered over $5 \mathrm{~mL}$ lymphocyte separation medium (TianJin Haoyang Biological Manufacture Co. Ltd., China). The splenocyte preparations were enriched by centrifugation $(2,000 \times \mathrm{g})$ for $15 \mathrm{~min}$ at room temperature. The cells were recovered from the interface, resuspended, and washed twice in PBS. The cells were suspended in RPMI-1640 medium [containing 10\% fetal bovine serum (FBS, Gibco, USA), and $1 \%$ antibiotic-antimycotic solution (Sigma, USA)]. The splenic lymphocyte density was adjusted to $1.5 \times 10^{6}$ cells $/ \mathrm{mL}$, and the viability of the freshly isolated cells was always above $95 \%$.

Transfection reactions were carried out using Lipofectamine 2000 transfection reagent (Invitrogen), following the manufacturer's instructions. The lymphocytes were transfected with various concentration of microRNAs using $2 \mu \mathrm{L}$ Lipofectamine 2000 in OptiMEM medium. For the monitoring the various parameters in the present investigation, the cells were treated for $24 \mathrm{~h}$ in the absence and presence of $20 \mu \mathrm{M} \mathrm{H}_{2} \mathrm{O}_{2}$ (the process of cell culture, transfection and the concentration of $\mathrm{H}_{2} \mathrm{O}_{2}$ were based on the study by Yu et.al,. [55, 56]).

\section{Dual luciferase reporter assay}

The pMIR-REPORT plasmids for the microRNA-155 target TNFRSF1B 3'UTR were constructed as wild-type (WT) pMIR-TNFRSF1B containing two tandem repeats of microRNA-155 response elements from TNFRSF1B 3'UTR or as mutant (MUT) pMIR-TNFRSF1B. The sequences of the single-stranded oligo pairs used to generate the pMIRTNFRSF1B (WT and MUT). The oligonucleotides were annealed and inserted into the pMIR-REPORT vector (Thermo Fisher). The empty vector (pMIR-REPORT) was used as the negative control. Cardiomyocytes were seeded in 24-well plates, and cells in each well were cotransfected pMIR-TNFRSF1B and miR according to the manufacturer's protocol. Twenty-four hours after transfection, luciferase activity was measured with the Dual Luciferase Assay System (Promega). The activity of Renilla luciferase was normalized to the activity of Firefly luciferase (Renilla LUC/ Firefly LUC).

\section{Determination of ROS generation in lymphocytes treated with $\mathrm{H}_{2} \mathrm{O}_{2}$}

The levels of ROS were measured using a detection kit from Beyotime Institute of Biotechnology (Nantong,
China) according to the manufacturer's instructions. Next, fluorescence distribution of the lymphocytes was detected by fluorospectrophotometer analysis at an excitation wavelength of $488 \mathrm{~nm}$ and at an emission wavelength of $525 \mathrm{~nm}$.

\section{TUNEL assay}

For TUNEL assay, the lymphocytes were collected after treatment. The TUNEL assay was performed to detect DNA fragmentation indicative of cell apoptosis with a commercial cell apoptosis detection kit (Roche, USA) according to the manufacturer's protocol. The apoptotic cells were photographed with an Inverted microscope (DMI4000, Leica, Germany) at 200× magnification.

\section{AO/EB-stained}

Apoptosis was determined morphologically after staining the cells with AO/EB followed by fluorescence microscopy inspection. After being transfected with microRNA-155 and treated with $\mathrm{H}_{2} \mathrm{O}_{2}$, the lymphocytes were stained with $\mathrm{AO} / \mathrm{EB}$ according to the manufacturer's instructions (Beyotime, Beijing, China).

\section{RNA isolation and real-time PCR (RT-PCR)}

For the quantification of microRNA-155 and mRNA of target genes by RT-PCR, total microRNANA and total RNA were isolated from the tissues and cultured cells. Reverse transcription was performed with the miRcute microRNA First-Strand cDNA Synthesis Kit (Tiangen Biotech Co. Ltd., Beijing) according to the manufacturer's instructions (Roche).

The primers for the detection of microRNA-155 and target mRNA by RT-PCR are shown in Table 1. RTPCR was performed on a LightCycler ${ }^{\circledR} 480$ II Detection System (Roche). Reactions were performed according to manufacturer's instructions (Tiangen Biotech Co. Ltd., and Roche). U6 and $\beta$-actin served as the endogenous controls for normalization. The expression of microRNA-155 and target mRNAs relative to $\mathrm{U} 6$ and $\beta$-actin, respectively, were calculated using the $2^{-\triangle \Delta C T}$ method [57]. We calculated the results with the following formulae: Ratio $=2^{-\Delta \Delta \mathrm{Ct}}, \Delta \Delta \mathrm{Ct}=\left(\mathrm{Ct}_{\text {target }}-\mathrm{Ct}_{\beta \text {-actin }}\right)_{\text {Sample }}-\left(\mathrm{Ct}_{\text {target }}{ }^{-}\right.$ $\left.\mathrm{Ct}_{\text {B-actin }}\right)_{\text {Control }}$

\section{Protein extraction and western blot (WB) analysis}

The protein samples were separated by $12 \%$ SDS-PAGE and transferred to PVDF membranes. The membranes were blocked with 5\% skim milk for $12 \mathrm{~h}$ and incubated for $1 \mathrm{~h}$ at $37^{\circ} \mathrm{C}$ with the following diluted primary antibodies: TNFRSF1B (1/100), c-Jun N-terminal kinase (JNK) (1/100), caspase3 (1/500), Bax (1/500) and Bcl-2 (1/100). After washing four times for 5 min each 
with PBST, the membranes were incubated for $1 \mathrm{~h}$ at $37^{\circ} \mathrm{C}$ with peroxidase-conjugated secondary antibodies against rabbit IgG (1/2000, Santa Cruz, USA). After washing four times for $5 \mathrm{~min}$ each, the bound antibodies were visualized by chemiluminescence using the ECL-plus reagent (GE Healthcare, Buckinghamshire, UK). The $\beta$-actin content was analyzed as the loading control with rabbit polyclonal antibody (Sigma, USA).

\section{Statistical analyses}

Statistical analyses of all data were performed using GraphPad Prism (version 5.0, GraphPad Software Inc., San Diego, CA, USA). The significant values ( $P$ $<0.05)$ were obtained by one-way ANOVA. All data displayed normal distribution and passed the test for equal variance. The data are expressed as the mean \pm $\mathrm{SD}$, and the differences were considered to be significant if $P<0.05$.

\section{Abbreviations}

RT-PCR, real-time PCR; WB, Western blot; TNFRSF1B, tumor necrosis factor receptor superfamily member 1B; miR-155m, microRNA-155 mimics; miR$155 \mathrm{mNC}$, microRNA-155 mimics negative control; miR-155i, microRNA-155 inhibitors; miR-155iNC, microRNA-155 inhibitors negative control; JNK, c-Jun N-terminal kinase.

\section{Author contributions}

Shu Li conceived and designed the experiments. Ci Liu, Zhepeng Sun, Zhe xu, Tianqi Liu, Tingru Pan performed the experiments. Ci Liu analyzed the data and wrote the paper. Shu Li assisted in critically revising the manuscript.

\section{ACKNOWLEDGMENTS}

The authors thank the members of the veterinary internal medicine laboratory at the College of Veterinary Medicine, Northeast Agricultural University for their help in collecting the spleen tissue samples.

\section{CONFLICTS OF INTEREST}

The authors declare that there are no conflicts of interest.

\section{FUNDING}

This study was supported by the National Natural Science Foundation of China (Grant No.31472161).

\section{REFERENCES}

1. Yu D, Zhang Z, Yao H, Li S, Xu SW. The role of selenoprotein $\mathrm{W}$ in inflammatory injury in chicken immune tissues and cultured splenic lymphocyte. Biometals. 2015; 28:75-87.

2. Broome CS, Mcardle F, Kyle JA, Andrews F, Lowe NM, Hart CA, Arthur JR, Jackson MJ. An increase in selenium intake improves immune function and poliovirus handling in adults with marginal selenium status. Am J Clin Nutr. 2004; 80:154-62.

3. Eskew ML, Scholz RW, Reddy CC, Todhunter DA, Zarkower A. Effects of vitamin $\mathrm{E}$ and selenium deficiencies on rat immune function. Immunology. 1985; 54:173-80.

4. Gairola C, Tai HH. Selective inhibition of leukotriene B4 biosynthesis in rat pulmonary alveolar macrophages by dietary selenium deficiency. Biochem Biophys Res Commun. 1985; 132:397-403.

5. Boyne R, Arthur JR. Alterations of neutrophils function in Se-deficient cattle. J Comp Pathol. 1979; 89:151-58.

6. Chang WP, Combs GF Jr, Scanes CG, Marsh JA. The effects of dietary vitamin $\mathrm{E}$ and selenium deficiencies on plasma thyroid and thymic hormone concentrations in the chicken. Dev Comp Immunol. 2005; 29:265-73.

7. Lei W, Yi H, Jing L, Wang H, Wang C, Duan M, He H. Selenium deficiency impairs host innate immune response and induces susceptibility to Listeria monocytogenes infection. BMC Immunol. 2009; 10:55.

8. Demelash A, Karlsson JO, Nilsson M, Björkman U. Selenium has a protective role in caspase-3-dependent apoptosis induced by $\mathrm{H} 2 \mathrm{O} 2$ in primary cultured pig thyrocytes. Eur J Endocrinol. 2004;150:841-9.

9. Shan H, Yan R, Diao J, Lin L, Wang S, Zhang M, Zhang $\mathrm{R}$, Wei J. Involvement of caspases and their upstream regulators in myocardial apoptosis in a rat model of selenium deficiency-induced dilated cardiomyopathy. J Trace Elem Med Biol. 2015; 31:85-91.

10. Yao HD, Wu Q, Zhang ZW, Zhang JL, Li S, Huang JQ, Ren FZ, Xu SW, Wang XL, Lei XG. Gene expression of endoplasmic reticulum resident selenoproteins correlates with apoptosis in various muscles of se-deficient chicks. J Nutr. 2013; 143:613-19.

11. Yao L, Du Q, Yao H, Chen X, Zhang Z, Xu S. Roles of oxidative stress and endoplasmic reticulum stress in selenium deficiency-induced apoptosis in chicken liver. Biometals. 2015; 28:255-65.

12. Zhang ZW, Zhang JL, Zhang YH, Wang QH, Li S, Wang $\mathrm{X}, \mathrm{Xu} \mathrm{S}$. Effect of oxygen free radicals and nitric oxide on apoptosis of immune organ induced by selenium deficiency in chickens. Biometals. 2013; 26:355-65.

13. Bartel D. MicroRNAs: Target Recognition and Regulatory Functions. Cell. 2009; 136:215-33. 
14. Dávila D, Jiménezmateos EM, Mooney CM, Velasco G, Henshall DC, Prehn JH. Hsp27 binding to the 3'UTR of bim mRNA prevents neuronal death during oxidative stress-induced injury: a novel cytoprotective mechanism. Mol Biol Cell. 2014; 25:3413-23.

15. Nie M, Liu J, Yang Q, Seok HY, Hu X, Deng ZL, Wang DZ. MicroRNA-155 facilitates skeletal muscle regeneration by balancing pro- and anti-inflammatory macrophages. Cell Death Dis. 2016; 7:e2261.

16. O'Connell RM, Rao DS, Chaudhuri AA, Boldin MP, Taganov KD, Nicoll J, Paquette RL, Baltimore D. Sustained expression of microRNA-155 in hematopoietic stem cells causes a myeloproliferative disorder. J Exp Med. 2008; 205:585-94.

17. Turner M, Vigorito E. Regulation of B- and T-cell differentiation by a single microRNA. Biochem Soc Trans. 2008; 36:531-33.

18. Slezak-Prochazka I, Kluiver J, de Jong D, SmigielskaCzepiel K, Kortman G, Winkle M, Rutgers B, Koerts J, Visser L, Diepstra A, Kroesen BJ, van den Berg A. Inhibition of the miR-155 target NIAM phenocopies the growth promoting effect of miR-155 in B-cell lymphoma. Oncotarget. 2016;7:2391-400. doi: 10.18632/ oncotarget.6165.

19. Zhu GF, Yang LX, Guo RW, Liu H, Shi YK, Wang H, Ye JS, Yang ZH, Liang X. miR-155 inhibits oxidized low-density lipoprotein-induced apoptosis of RAW264.7 cells. Mol Cell Biochem. 2013; 382:253-61.

20. Gironella M, Seux M, Xie MJ, Cano C, Tomasini R, Gommeaux J, Garcia S, Nowak J, Yeung ML, Jeang KT, Chaix A, Fazli L, Motoo Y, et al. Tumor protein 53-induced nuclear protein 1 expression is repressed by miR-155, and its restoration inhibits pancreatic tumor development. Proc Natl Acad Sci USA. 2007; 104:16170-75.

21. Macieldominguez A, Swan D, Ford D, Hesketh J. Selenium alters miRNA profile in an intestinal cell line: evidence that miR-185 regulates expression of GPX2 and SEPSH2. Mol Nutr Food Res. 2013; 57:2195-205.

22. Matthews JC, Zhang Z, Patterson JD, Bridges PJ, Stromberg AJ, Boling JA. Hepatic transcriptome profiles differ among maturing beef heifers supplemented with inorganic, organic, or mixed (50\% inorganic:50\% organic) forms of dietary selenium. Biol Trace Elem Res. 2014; 160:321-39.

23. Yang Z, Liu C, Liu C, Teng X, Li S. Selenium Deficiency Mainly Influences Antioxidant Selenoproteins Expression in Broiler Immune Organs. Biol Trace Elem Res. 2016; 172:209-21.

24. Yang Z, Liu C, Zheng W, Teng X, Li S. The Functions of Antioxidants and Heat Shock Proteins Are Altered in the Immune Organs of Selenium-Deficient Broiler Chickens. Biol Trace Elem Res. 2016; 169:341-51.

25. You L, Liu C, Yang ZJ, Li M, Li S. Prediction of selenoprotein $\mathrm{T}$ structure and its response to selenium deficiency in chicken immune organs. Biol Trace Elem Res. 2014; 160:222-31.
26. Wu T, Xie M, Wang X, Jiang X, Li J, Huang H. miR-155 modulates TNF- $\alpha$-inhibited osteogenic differentiation by targeting SOCS1 expression. Bone. 2012; 51:498-505.

27. Xue XY, Liu YX, Wang Y, Meng MM, Wang KF, Zang XF, Zhao S, Sun XH, Cui L, Pan L, Liu SH. MiR-21 and MiR155 promote non-small cell lung cancer progression by downregulating SOCS1, SOCS6, and PTEN. Oncotarget. 2016; 7:84508-19. doi: 10.18632/oncotarget.13022.

28. Tili E, Michaille JJ, Cimino A, Costinean S, Dumitru CD, Adair B, Fabbri M, Alder H, Liu CG, Calin GA, Croce CM. Modulation of miR-155 and miR-125b Levels following Lipopolysaccharide/TNF- $\alpha$ Stimulation and Their Possible Roles in Regulating the Response to Endotoxin Shock. J Immunol. 2007; 179:5082-89.

29. Liu F, Kong X, Lv L, Gao J. MiR-155 targets TP53INP1 to regulate liver cancer stem cell acquisition and self-renewal. Febs Letters. 2015; 589:500-506.

30. Ceppi M, Pereira PM, Dunandsauthier I, Barras E, Reith W, Santos MA, Pierre P. MicroRNA-155 modulates the interleukin-1 signaling pathway in activated human monocyte-derived dendritic cells. Proc Natl Acad Sci USA. 2009; 106:2735-40.

31. Horie T, Dobashi K, Iizuka K, Yoshii A, Shimizu Y, Nakazawa T, Mori M. Interferon-gamma rescues TNFalpha-induced apoptosis mediated by up-regulation of TNFR2 on EoL-1 cells. Exp Hematol. 1999; 27:512-19.

32. Li M, Liu Y, Xia F, Wu Z, Deng L, Jiang R, Guo FJ. Progranulin is required for proper ER stress response and inhibits ER stress-mediated apoptosis through TNFR2. Cell Signal. 2014; 26:1539-48.

33. Min W, Wan T, Luo Y. Dissecting TNF-TNFR1/TNFR2 signaling pathways in vasculature. Springer Basel. 2010; 2010:137-59.

34. Pimentel MF, Seed B. Regulated commitment of TNF receptor signaling: a molecular switch for death or activation. Immunity. 1999; 11:783-93.

35. Vandenabeele P, Goossens V, Beyaert R, Declercq W, Grooten J, Vanhaesebroeck B, Van de Craen M, Vercammen D, Depuydt B, Denecker G. Functional requirement of the two TNF receptors for induction of apoptosis in PC60 cells and the role of mitochondria in TNF-induced cytotoxicity. Circ Shock. 1995; 44:196-200.

36. Ramesh G, Reeves WB. TNFR2-mediated apoptosis and necrosis in cisplatin-induced acute renal failure. Am J Physiol Renal Physiol. 2003; 285:F610-18.

37. Grell M, Zimmermann G, Hülser D, Pfizenmaier K, Scheurich P. TNF receptors TR60 and TR80 can mediate apoptosis via induction of distinct signal pathways. Journal of immunology (Baltimore, Md : 1950). 1994; 153:1963-1972.

38. Haridas V, Darnay BG, Natarajan K, Heller R, Aggarwal BB. Overexpression of the $\mathrm{p} 80 \mathrm{TNF}$ receptor leads to TNFdependent apoptosis, nuclear factor-kappa B activation, and c-Jun kinase activation. J Immunol. 1998; 160:3152-62. 
39. Cheng EH, Wei MC, Weiler S, Flavell RA, Mak TW, Lindsten T, Korsmeyer SJ. BCL-2, BCL-XL Sequester BH3 Domain-Only Molecules Preventing BAX- and BAK-Mediated Mitochondrial Apoptosis. Mol Cell. 2001; 8:705-11.

40. Wei Y, Sinha S, Levine B. Dual Role of JNK1-mediated phosphorylation of Bcl-2 in autophagy and apoptosis regulation. Autophagy. 2008; 4:949-51.

41. Jürgensmeier JM, Xie Z, Deveraux Q, Ellerby L, Bredesen D, Reed JC. Bax directly induces release of cytochrome c from isolated mitochondria. Proc Natl Acad Sci USA. 1998; 95:4997-5002.

42. Liang S, Sun K, Yue W, Dong S, Cheng W, Liu LX, Wu YH. Role of Cyt-C/caspases-9,3, Bax/Bcl-2 and the FAS death receptor pathway in apoptosis induced by zinc oxide nanoparticles in human aortic endothelial cells and the protective effect by alpha-lipoic acid. Chem Biol Interact. 2016; 258:40-51.

43. Yuan S, Wu B, Yu Z, Fang J, Liang N, Zhou M, Huang $\mathrm{C}$, Peng X. The mitochondrial and endoplasmic reticulum pathways involved in the apoptosis of bursa of Fabricius cells in broilers exposed to dietary aflatoxin B1. Oncotarget. 2016; 7:65295-65306. doi: 10.18632/oncotarget.11321.

44. Liu G, Wang ZK, Wang ZY, Yang DB, Liu ZP, Wang L. Mitochondrial permeability transition and its regulatory components are implicated in apoptosis of primary cultures of rat proximal tubular cells exposed to lead. Arch Toxicol. 2016; 90:1193-209.

45. Zhang Z, Bi M, Liu Q, Yang J, Xu S. Meta-analysis of the correlation between selenium and incidence of hepatocellular carcinoma. Oncotarget. 2016; 7:7711077116. doi: 10.18632/oncotarget.12804.

46. Yao HD, Wu Q, Zhang ZW, Shu L, Wang XL, Lei XG, $\mathrm{Xu}$ SW. Selenoprotein W serves as an antioxidant in chicken myoblasts. Biochimica Et Biophysica Acta. 2013; 1830:3112.

47. Yao H, Liu W, Zhao W, Fan R, Zhao X, Khoso PA, Zhang $\mathrm{Z}, \mathrm{Xu}$ S. Different responses of selenoproteins to the altered expression of selenoprotein $\mathrm{W}$ in chicken myoblasts. RSC Advances. 2014; 4:64032-42.

48. Yao H, Zhao W, Zhao X, Fan R, Khoso PA, Zhang Z, Liu W, Xu S. Selenium Deficiency Mainly Influences the Gene
Expressions of Antioxidative Selenoproteins in Chicken Muscles. Biol Trace Elem Res. 2014; 161:318-27.

49. Wang H, Zhang T, Sun W, Wang Z, Zuo D, Zhou Z, Li S, Xu J, Yin F, Hua Y, Cai Z. Erianin induces G2/M-phase arrest, apoptosis, and autophagy via the ROS/JNK signaling pathway in human osteosarcoma cells in vitro and in vivo. Cell Death Dis. 2016; 7:e2247.

50. Li B, Sun M, Gao F, Liu W, Yang Y, Liu H, Cheng Y, Liu C, Cai J. Up-Regulated Expression of miR-23a/b Targeted the Pro-Apoptotic Fas in Radiation-Induced thymic Lymphoma. Cellular Physiology \& Biochemistry International Journal of Experimental Cellular Physiology Biochemistry \& Pharmacology. 2013; 32:1729-40.

51. Yang Q, Jiang W, Zhuang C, Geng Z, Hou C, Huang $\mathrm{D}$, Hu L, Wang X. microRNA-22 downregulation of galectin-9 influences lymphocyte apoptosis and tumor cell proliferation in liver cancer. Oncol Rep. 2015; 34:1771-78.

52. Koch M, Mollenkopf HJ, Klemm U, Meyer TF. Induction of microRNA-155 is TLR- and type IV secretion systemdependent in macrophages and inhibits DNA-damage induced apoptosis. Proc Natl Acad Sci USA. 2012; 109:E1153-62.

53. Yao H, Fan R, Zhao X, Zhao W, Liu W, Yang J, Sattar H, Zhao J, Zhang Z, Xu S. Selenoprotein W redox-regulated $\mathrm{Ca} 2$ channels correlate with selenium deficiency-induced muscles $\mathrm{Ca}^{2}$ leak. Oncotarget. 2016; 7:57618-32. doi: 10.18632/oncotarget.11459.

54. Xu J, Lian LJ, Wu C, Wang XF, Fu WY, Xu LH. Lead induces oxidative stress, DNA damage and alteration of p53, Bax and Bcl-2 expressions in mice. Food \& Chemical Toxicology An International Journal Published for the British Industrial Biological Research Association. 2008; 46:1488-94.

55. Yu D, Zhang ZW, Yao HD, Li S, Xu SW. Antioxidative role of selenoprotein $\mathrm{W}$ in oxidant-induced chicken splenic lymphocyte death. Biometals. 2014; 27:277-91.

56. Liu Y, Peng JP, Huang HW, YH Q. Comparetion of different method of transfection lymphocyte. Med J of Communications. 2010; 24:608-11.

57. Livak KJ, Schmittgen TD. Analysis of relative gene expression data using real-time quantitative PCR and the 2(-Delta Delta C(T)). Method. Methods. 2001; 25:402-08. 